\title{
AN ANALYSIS OF THE MOTIVATION REFLECTED BY THE MAIN CHARACTERS IN THE MOVIE "42" AND ITS PERSONALITY INFLUENCE
}

\author{
Dewi Mutiara Indah Ayu \\ Program Studi Pendidikan Bahasa Inggris \\ Fakultas Bahasa dan Seni Universitas Indraprasta PGRI \\ Jl. Nangka 58 C Tanjung Barat, Jakarta Selatan \\ mutiaradewi27@yahoo.com
}

\begin{abstract}
The aim of the research is to find out how motivation is reflected by the main characters in the movie "42", the effort that Jackie and Rickey make in order to fulfill the needs and to analyze the influence of personality on motivation of the main characters. The writer uses qualitative descriptive research in observing the motivation of the main characters of the Movie "42". The writer limited the data which are classified them into different level needs based on Maslow's Hierarchy of Human Need theory. However, the writer sees that the main characters had different level of needs structure as their salient. Such as : As for Jackie, the writer found that from 5 level of Maslow's Hierarchy of Human Needs, there were 2 salient needs; the belongingness and love needs, and the self-esteem need. As for Rickey, there was just 1 need he had to fulfill; the self-actualization need. The writer also noticed the process to fulfill the needs from one level needs to the higher one was not always in a hundred percent to be fulfilled, otherwise the lower need could partly fulfilled so we could go to the higher one as motivation.
\end{abstract}

Key words: Motivation, Personality, Racism, Hierarchy of Human Needs.

\begin{abstract}
Abstrak
Tujuan dari penelitian ini adalah untuk menemukan bagaimana motivasi tergambar dari karakter tokoh utama film "42", upaya-upaya yang dilakukan Jackie dan Rickey dalam memenuhi kebutuhannya dan menganalisa pengaruh motivasi terhadap kepribadian tokoh utama. Metode penelitian ini adalah metode kualitatif. Penulis membatasi data dengan mengklasifikasikan menjadi tiga kelompok tingkatan kebutuhan yang berbeda-beda berdasarkan teori hirarki kebutuhan Maslow. Dalam penelitian ini, dapat ditarik kesimpulan bahwa motivasi muncul akibat adanya dorongan untuk memenuhi tingkatan kebutuhan yang paling dasar sampai ke tingkatan yang paling tinggi, namun penulis menemukan bahwa setiap tokoh utama memiliki tingkatan kebutuhan yang berbeda-beda sesuai dengan kebutuhannya yang paling penting. Contohnya, untuk Jackie, penulis menemukan bahwa dari 5 tingkatan kebutuhan Maslow, terdapat 2 kebutuhan yang sangat penting untuk Jackie yaitu kebutuhan rasa cinta dan memiliki, dan kebutuhan rasa penghargaan. Sedangkan untuk Rickey, penulis menemukan bahwa dari 5 tingkatan kebutuhan tersebut, hanya terdapat 1 tingkatan kebutuhan yang harus dipenuhi olehnya, yaitu kebutuhan untuk mengaktualisasikan diri. Penulis juga menemukan bahwa, proses untuk pemenuhan kebutuhan dari satu tingkatan ke tingkatan yang lebih tinggi tidak selalu harus seratus persen terpenuhi, namun jika kebutuhan dari tingkatan bawah sudah terpenuhi sebagian maka akan muncul kebutuhan lainnya sebagai motivasi untuk terpenuhi.
\end{abstract}

Kata Kunci: Motivasi, Kepribadian, Rasisme, Tingkat Kebutuhan Manusia.

\section{INTRODUCTION}

Racial discrimination in America is not something new. Racial and ethnic segregation have occurred since 1941 when the Jim Crow Law was put into effect. The impact of the law is still felt until today-discrimination in 
workplaces, educational institutions, and health facilities are still a common phenomenon. It is thus this social phenomenon marked by the various conflicts that has aroused the desire of the writer to do some research on the internal psychological aspects as portrayed by the minority group in facing the existing reality and how they manage to survive and successfully become pioneers of Human Rights. The writer has intentionally chosen Brian $\mathrm{He}$ gland's film entitled " 42 " as the object of research since the scenes also concurrently serve to represent the motivation and personality displayed by the main characters in their attempts to make their dreams come true and change the paradigms of the white Americans concerning the blacks." 42 " is a biographical drama film which depicts the internal psychological conflicts sparked by racial discrimination as experienced by the main characters. It highlights conditions in America in PostWorld War II, in the year 1945. It is based on the true story about the first African-American baseball player, Jackie Robinson, who managed to gain acceptance in the White Major Leagues Baseball. However, it is Jackie Robinson who suffers the most. He has to persevere all the taunts from not only his team mates but also other team coaches and spectators only because he is black. It is all these that have made the film an interesting object of analysis in this research. Furthermore, the movie " 42 " represents an American historical right movement movie for African-American people, especially in baseball, because it serves as the source of inspiration for some freedom fighters of the same era, such as : Martin $\mathrm{J}$ Luther King and Malcom X. All in all the movie depicts a historic moment when the practice of discrimination and prejudice against blacks especially in baseball that has prevailed for decades ended. This movie contains a historical lesson in which we learn about how the people of America change their perspective of, and prejudice against certain life principles and accept changes. Thus from this film we can learn what the American of the past values most in their life and that paradigms can change over time. Another reason why the movie " 42 " is one of the best social critics film in the United State is the fact that it has won three awards from ; African-American Film Critics Association (AAFCA) in 2013 , the Best Foreign Language in Hochi Film Awards, 2013. the Best Audio/visual technique and best trailer in Key Art Awards. (http://www.imdb.com/title/tt0453562/a wards, 5 Sept 15)

\section{METHOD}

This study uses a qualitative descriptive method. Creswell (in Sugiyono, 2013:228) stated that qualitative research is a means of exploring and understanding the meaning individuals or groups ascribed to a social human problem. The process of research involves emerging questions and procedures; collecting data in the participants' setting; analysing the data inductively, building from particulars to general themes; and making interpretations of the meaning of data. The final written report has a flexible writing structure. According to Creswell (2012), there are five kinds of method in qualitative research. Phenomenological research, grounded theory, ethnography, case study, and narrative research. Phenomenological research is a qualitative strategy in which the researcher identifies the essence of human experiences about a phenomenon as described by the participant in a study. Grounded theory is a qualitative strategy 
in which the researcher derives a general, abstract theory of a process, action, or interaction grounded in the views of the participants the study. Ethnography is a qualitative strategy in which the researcher studies an intact cultural group in a natural setting over prolonged period of time by collecting primarily observational and interview data. Case studies are qualitative strategy in which the researcher explores in depth a program, event, activity, process, or one or more individuals. Narrative research is a qualitative strategy in which the researcher studies the kinds of individuals and asks one or more individuals to provide stories about their lives. This information is then often retold or restored by the researcher into a narrative chronology. Because of the subject research is the main character of the movie that describe the success story and their struggle achieving goals, the writer use narrative strategy and audiovisual in analysing the main characters in movie 42.

\section{DISCUSSION}

After analysing the data in sub chapter $\mathrm{A}$ and $\mathrm{B}$, the writer attempts associate the data into needs of the main characters based on Maslow's Hierarchy of Human Needs theory by table and chart in order to make easy the reader.

Table 4.1

The Recapitulation of The Motivation of The Main Characters to Fulfill The Needs

\begin{tabular}{|l|c|c|c|}
\hline \multirow{2}{*}{ NO } & $\begin{array}{c}\text { The Main } \\
\text { Characters }\end{array}$ & The Hierarchy of Human Needs & $\begin{array}{c}\text { Total Effort to } \\
\text { fulfill the needs }\end{array}$ \\
\hline \multirow{2}{*}{1} & Jackie Robinson & Belongingness and Love Needs & 7 \\
\cline { 3 - 4 } & & The Self-Esteem Needs & 2 \\
\hline 2 & Branch Rickey & The Self-Actualization Needs & 9 \\
\hline
\end{tabular}

Chart 4.1

The Chart of The Motivation of The Main Characters to Fullfill The Needs

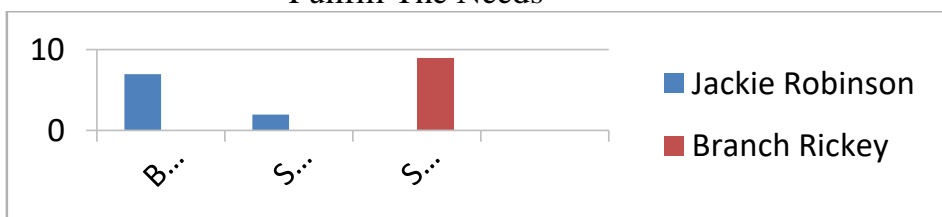

(Source : The Writer's Analysis)

From the analysis of the data above, the writer had found that there were three needs as the motivation of the main characters in the movie " 42 " to reach the goals. As for Jackie, the writer found two needs based on the Maslow's Hierarcy of Human Needs theory; The Belongingness and Love Needs, and The Self-Esteem Needs. Whereas for Rickey, the motivation was to fulfill the Selfactualization Needs. Below were the examples of the fulfilment of the main characters' needs and how its influence on their personality :

\section{Jackie Robinson}

The writer had found nine (9) effort to fulfil the needs as his motivation to reach the goals. The motivation was 
divided into two level of needs; the belongingness and love needs (7 effort) and the self-esteem needs ( 2 effort) :

The Effort to Fulfil The

Belongingness and Love Needs

(1)Attempting to control his temper

(2)Following Wendell Suggestion

(3)Ignoring the harassment of the white spectators

(4)Tricking Higbe in the Pitch

(5)Leaving the pitch instead of fighting with the police

(6)Getting the support of Rickey

Getting the first base position in Montreal Royal

The Effort to Fulfil The Self-

Esteem Needs :

(1)Keeping his temper under control

(2)Retaining his position in the team

Personality Aspect of Jackie

Robinson

(1)He has strong personality and motivation to manage all those deprivation that he had as stimulant for to move forward.

(2)He was a ble to supress his ego as a means to counter people's prejudice.

(3)He was able to convince Rickey and Brooklyn's management.

(4)Jackie could be described as mature individual

(5)Jackie was able to cope with the various forms of adverse situation blending his feelings with the perception of the whites and the Craw Law.

(6) $\mathrm{He}$ had a positive attitude and behaviour that led to a change in the perception of his teammate and the whites of him.

As the result of the effort, the writer found the achievement of Jackie in his life and carrier, such as :

1. Accept Himself

2. Acceptance of his teammates

3. Acceptance of the white spectators

\section{Branch Rickey}

The writer had found 9 (nine) effort to fulfill the needs of Rickey as his motivation to reach the goal. The description would be described as follow:

The Effort to Fulfill The SelfActualization Needs :

(1)Convincing his management to accept black player

(2)Searching for black players in order to reach his goal

(3)Asking Hopper to treat Jackie equally

(4)Banishing the petition from his player

(5)Convincing the Commissioner of

Baseball about the Durocher Scandal

(6)Searching for a new coach for Brooklyn Dodgers

(7)Arguing with Phille's general manager

(8)Convincing Pee Wee Reese

(9)Rickey rejected unfairness in baseball Personality Aspect of Branch

Rickey

(1)He had the courage to take any risk in order to strengthen his club.

(2)He was a democratic person who wanted to see everybody playing baseball without worrying about his or her skin color.

(3)Rickey had managed to actualized himself in the baseball world.

Below were given such examples of Rickey's achievement in baseball :

1. Jackie Robinson signing a contract with the Brooklyn Dodgers

2.The Brooklyn Dodgers management acceptance of Jackie

3.Changes in the attitude of the white people towards in the blacks

\section{The Motivation and Personality of Jackie Robinson and Branch Rickey}

In this sub-chapter, The Focus of the research is the belongingnees and love needs, and the self-esteem needs of Jackie Robinson, and the needs for selfactualization of Rickey and how 
motivation influence the personality of the main characters. An explanation on the process of the fulfillment of the main character's need based on Victor Vroom theory of expectancy.

For Jacky, the writer has chosen to focus on belongingness and love needs, and self-esteem needs for the following reasons : 1) in the beginning of the movie, Jackie has already been known to be a professional player, though only in the Negro-League. Thus, it can be assumed that his physiological needs is more or less fulfilled. 2) when he was hired by Brooklyn Dodgers, his safetyneed was partial fulfiled by Rickey, 3) the threats, taunts, rejection he experiences when playing in the white team were forms of the obstacles he had to face while searching for belongingness, love needs and recognition (self-esteem) from the Whites.

As for Rickey, the selfactualization need has been made the focus on the premise that Rickey being a white man, and an owner of a professional baseball team, he was by far better off than Jackie and, therefore, his needs were naturally of a higher level than Jacky's. In the movie it could be seen that his main concern was the integration of Negro in the national baseball leagues.

Below is a description of the issues of Jackie Robinson and Branch Rickey, and the attempts they made to fulfill those needs.

\section{The Motivation of Jackie Robinson}

1. Issue

The writer identifies two needs of Jackie that have served to motivate him to reach his goals. These, according to Maslow's theory of Hierarchy of Needs, are the fulfillment of the belongingness needs and the love need, and the fulfillment of his self-esteem needs, particularly because of the various rejections he had encountered only because he belonged to the minority groups.

As a matter of fact, prior to the analysis of above mention needs, the writer has also analysed the proponent needs (lower need) of Jackie first. The prepotent need of Jackie is the physiology needs (money) and the safety needs. As can be seen in the beginning of the movie, Jackie appears as a baseball player in the Negro Leagues in the scene (min. 00:04:56).

As such the writer assumes Jackie has more or less fulfill his physiology needs. by joining white baseball team, by his association with Rickey, Jackie can be said partly fulfilled his safety needs .

Below is a description of Jackie's endeavour to achieve his belongingness and love needs, as well as his acceptance needs.

2. The Effort of Jackie Robinson to Fulfil his Belongingness and Love Needs

The Maslow theory on the hierarchy of Human Needs stated that if the physiology needs and the safety needs are well gratified, there will emerge the love, affection and belongingness need. If people deprived of those needs, he or she will then strive to achieve them, i.e. to gain the affection of people in general.

In Jackie 's case, the writer find that Jackie was very much in need for belongingness and affection by his teammates and white spectators, and other team coaches and players. He could not get along well with his teammate in Brooklyn due to Racial segregation, imposed by the state with its Craw Law. His 
white mates seemed to underestimate his ability, abusing him verbally and physically, only because he was black.

Further, in his efforts to gain acceptance, Jackie took the following steps :

a. Attempting to Control his Temper.

Jackie was requested by Mr. Rickey to control his temper when playing in the field with other white team player. Rickey asked Jackie to have the guts not to fight back in the pitch when provoked. This can be seen in the dialogue min (00:11:12) below : Dialogue minute 00:11:12

Jack : Do you want a ballplayer who doesn't have the guts to fight back?

Rickey : No. I want one who has the guts not to fight back!

From the dialogue above, Rickey advised Jackie to have the guts to respond to all the taunts without violence. This implies Rickey had already predicted what the reaction of the whites would be-- the insults a black player in would suffer in a White baseball team, Rickey made no attempt to hide the truth and told Jackie all about the possible maltreatment that he would be receiving when staying in luxurious hotel, e.g. reception's rejection and waiter's refusal to take his order or serve meals for him in restaurants.

Indeed, it was hard for Jackie to put up with the many taunts and refusal from his teammates. Rickey, however, insisted that Jackie not ruin all his plans by his reaction to fight them back on provocation. The situation is described as follow below

Dialogue minute 00:11:55

Rickey : We win by hitting, running and fielding, nothing else. We win if the world is convinced of two things: that you are a fine gentlemen and a great ballplayer. Can you do that ?

As the writer sees from the dialogue in $\min$ (00:11:55) above, that Rickey wanted to know what kind of a man Jackie was and what kind of a baseball player he was. Rickey want to see Jackie playing baseball in the same field with the white players for the first time, so he convinced Jackie that he could only fight by hitting, running, and fielding.

Jackie seemed offended at first; he felt he was insulted by Ricky, but in the end he asked Rickey to give him a number on his back before he could give him that gut.

Dialogue Min 00:12:39 to 00:12:53

Jackie: Give me a uniform, give me a number on my back, and I'll give you the guts.

From the text above, it was obvious that Jackie was not afraid of the challenge from Rickey, the general manager of Brooklyn Dodgers. He was not a coward. Jackie agreed to what Rickey had offered him. Playing for the affiliate team of Brooklyn Dodgers- Montreal Royals for Spring Training before signing contract with the Dodgers.

The writer noticed that in these scene, Jackie displayed his motivation to prove that he was good enough to be accepted in a White baseball. By convincing Rickey that he was able control 
his temper in the field and not to fight back, is he was trying to gain the attention of his teammate and white spectators. Jackie's behaviour was compatible with the Expectancy theory of Victor V rooms which states that every person believes that there is a relationship between the effort they put forth at work, the performance they achieve from the effort, and the reward from their effort and performance. Jackie believes that if he does well in the pitch, the spectators will accept him.

b. Following Wendell Suggestion

This can be seen in the scene when Wendell gave an advice to Jackie on how to deal with reporters who might be asking him about his skin .

Wendell told Jackie to be mentally prepared if he was rained by many racial questions out there . By Wendell's advised. Jackie managed to answer all their provocative question calmly.

Dialogue minute 00:20:58 to 00:21:08

Smith: What about if there's one white pitcher throw a ball at you?.

They will try to ask about your skin. You need to be ready.

Jack: If they ask something, I'll answer... Well, you want to see the questions come in slow, too.

Jackie follows Smith suggestion about how to answer for reporters who mostly will ask about his skin. This is depicted in a scene (min 00:21:30) that the reporters asked whether he can make with white players and Jackie replied gently that he has no problem with white players because he has served for UCLA (the university of California) where mostly of the student were white people.

Dialogue minute 00:21:35 to 00:21:43

Reporter Two: What'll you do if one of these pitchers throws at your head?

Jack : (thinks a beat) I'll duck.

c. Ignoring The Harassment of The White Spectators

Another proof of what Jackie did to realize his effort was that trying to ignore the mockery of the white spectators. They didn't seem to like Jackie's presence as a player in the team of whites. In one scene, (min.00:25:59) we see that not on rare occasion was Jackie despised by the whites with such comments as 'get out of here, Nigger', 'you don't deserve to play here'.

Jackie tried to ignore all the curse and kept concentrating on the game. It was Rachel Robinson, his wife, who was there, watching him that had encouraged him to do his best. She event convinced Wendell that Jackie would be able to get through all these ordeals. The scene can be followed in (00:26:07)

Dialogue minute 00:26:07

Rachel: Jack's got a thick skin. He'll be okay...

I better get one in a hurry.

From the dialogue above, the writer can see that Rachel believed that Jackie had the strength to fight all the racial taunts, Rachel believed that her husband was born to be a survivor. The presence of Rachel 
in the field had provided Jackie with the strength to overcome any undesired situation.

d. Tricking Higbe in the Pitch

From the picture in minute (min.00:28:51), we can see that Jackie tried to deceive, thus, distracting him away from the batter, instead of focus his attention on the batter. Higbe focused on Jackie was then behind the batter, his stance showing as if he was ready to run to the next base. His trick did work. Higbe threw the ball to the base that Jackie was in thereupon Jackie ran back hurriedly to his previous base and was declared "safe" by the umpire. this is shown in minute $(00: 28: 32)$

Jackie received threats from Kirby, this didn't scare him. Jackie knew well that his opponents were panic, and that his team could take advantage of the situation. Kirby, bulked by the situation, dropped. Thus Jackie as the runner was able to get to the home-base effortlessly, and Montreal got the score.

e. Leaving the Pitch Instead of Fighting With the Police

Jackie is described as a man who consistent kept his promise. This is depicted in the (00:36:39) when he was driven away from the field despite the fact that he had not done anything wrong. He was acused of offending the law only because he was a negro playing baseball with the whites. Thus, he had to choose between two alternatives: Either leave the pitch or go to jail. Dialogue minute 00:36:39

Policeman: Git off this field now!...
Jackie tried not to fight back. All he said when the police wanted to swing the stick was that he would rather he bit by him. when Hopper, his manager in Montreal Royal, approached to see what's going on, the police told him to get Jackie out of the field because he was ill-gotten. He said that the people in Florida couldn't accept his presence in the field, Brooklyn was in no position to change their ways of life, separated whites and blacks. Being abuse by the policeman, Jackie chose to avoid the further arguments and immediately, left the pitch. Montreal lost 2-1.

The scene shows us that Jackie chose to get out of the field instead of having a quarrel with the police. He also did not want to give up playing baseball. And $\mathrm{He}$ simply called him names.

f. Getting the Support of Rickey Rickey was very glad to tell Jackie that he had already managed to make all arrangements required for him to play for Montreal Royal. Therefore, he wants Jackie to come to the opening Jersey, together with the all-white players of Dodgers. Jackie agreed and ensured Rickey that he would not disappoint him.

Dialogue minute 00:39:17 to 00:39:34

Jack : Why are you doing this, Mr. Rickey?

Rickey : I'm an opportunist. With you and the Negro players I hope to bring up next year I'll put together a team that can win the World Series. And the World Series means money. 
From the dialogue above, the writer found that Rickey had a great expectations, presence in his team would be on encouragement for other black players to join his team of whites, thus increasing its chance to win the worldseries. Rickey believed that the world series would bring in more money because not only the whites but also the blacks will be swarming the stadium to watch it.

Dialogue minute 00:39:41 to 00:40:07

Rickey : Don't you believe that? Jack : I don't think what I believe is important. Only what I do...

The dialogue in minute (00:39:41) reflects the personality of Jackie. he was type of the person who would never bother about what other people had to say about him, or whether the white people liked him or not, the only thing that he had in mind was the match and what he would do in the filed to win not only the match but also the hearts of the spectators- the black and whitethereby gaining their honor.

And Rickey had never since stopped encouraging him to stay strong in the face of all the pathetic situations.

g. Getting the First Base Position in Montreal

The writer sees in minute (00:49:41) that in Montreal, Jackie was assigned to play as first baseman by Clyde. Jackie hesitated at first, because he had never before been plating as the first baseman.

Dialogue minute 00:49:41to 00:49:49
Sukeforth :Robinson! As Jack turns, Sukeforth tosses him a First Baseman's Glove...

Dialogue minute 00:50:20 to 00:50:39

Sukeforth: Mr. Rickey said he wants you playing conspicuous baseball!...

From the scene the writer see, a good performance will lead to a good outcome, it is described in the scene above, telling us that Jackie has got a chance to play as first baseman after he exercised in particular game.

3. The Effort of Jackie Robinson to Fulfill His Self-Esteem Needs

As soon as Jackie had been able to convince Rickey and the management he did have what the needed of him as a professional baseball player and that he could get along well with the others, Jackie was seen to be making a move towards the next level of Maslow's Hierarchy of Needs - the self-esteem needs.

As Maslow states in his theory of Hierarchy of Human Needs that every individual in the society have a need or desire for a stable and firm base. This includes the desire for strength, achievement, competence, confidence in the face of the world, independence, and freedom. At the next level is the desire for reputation, status, recognition, attention, collectively termed as the need for self-esteem.

Given his situation as described, Jackie is strongly motivated to improve his performance in the field in order to prove that he deserved a place in the team, to win the hearts of the white spectators, thus fulfilling selfesteem. 
a. Keeping His Temper Under Control

Jackie continued to experience verbal abuses from the coach of Phillies Baseball club, Ben Chapman, who kept yelling at him with sarcastic remarks bearing racial nuances, calling him names, niggers, and so on. Jackie simply didn't belong there; he should have been playing in the International league, the all-blacks league. From the edge of the pitch, Chapman kept shouting insults at him, yelling at him names, trying to tear apart his concentration on the match, but Jackie stayed cool as he kept concentrating on the pitcher, in the Chapman continued to despise and insult him, shouting nasty words at him. The situation is captured in the dialogues below :

Dialogue minute 01:13:34

Chapman: Why don't you go back to the cotton fields where you belong!

Dialogue minute 01:16:24

Chapman : Hey, Pee Wee! Dixie! What's this Nigger doing for you all to let him drink from the same water fountain as you?! I hope you don't take a shower with him. You gonna be mess !

Dialogue minute 01:17:46

Chapman : You don't belong! Look in a mirror! This is a white man's game. Get it Through your thick monkey skull!

From the dialogues above, the writer concludes that Chapman was trying to distract Jackie such that would not perform well enough to qualify for the match. Chapman seemed to represent those white people who simply loathed Jackie's presence in the white club. Jackie simply turned a deaf ear to what Chapman was saying, while Chapman continued with his verbal harassments. . It was not until Chapman asked him whether he liked white women and which of the women from the Brooklyn team he would like to sleep with that Jackie lost control of his temper. In reaction to this sarcasm Jackie requested for a moment's time out. Chapman kept making fun of him, saying that he would be sleeping Jackie's wife Dixie that night. Again Jackie hit the ball out of the pitch. Jackie was seen to be really $\mathrm{mad}$ at the situation in minutes 01:19:29 of the scene.

Dialogue minute 01:19:21 to 01:20:09

Minute 01:19:21

Rickey: If you fight, they won't say Chapman forced you to; they'll just say that you're over your head.

That you belong where you are... In the dialogue above the writer sees that Jackie felt hopeless, there was nothing he could do, however, Rickey convinced him that there were things he could do to fight Chapman. All he needed to do was to get back into the pitch and grab all the scores. If he fought Chapman back and physically attacked him, no one would take side with him. Instead, he would be blamed for provoking the fight and nobody would defend him. Jackie would lose the support of those who trusted, loved, and needed him right now. 
b. Retaining for His Position in the Team

The writer sees that one of Jackie teammates in the Brooklyn team doesn't felt like offended by such treatment. The scene is depicted in $\min$ (01:32:01-01:32:51)

Dialogue minute 01:32:01

Walker: Maybe 42's got enough friends in town, we can bunk up...

In the dialogue above, the writer notices that Jackie was determined to stand his ground, even if Walker kept intimidating him and tried to get rid of him. Jackie was determined to win the match despite their being rejected by the hotel.

4. Personality Aspect of Jackie Robinson

From the description in pervious sub chapter, the writer analyses that Jackie was a person of strong personality because he had managed to all those deprivation that he had had as stimulants for to move forward. He was able to suppress his ego first as a means to counter people's prejudice. He was able to convince Rickey and Brooklyn's management that he was trustworthy and that he can manage to do the best for the team by scoring and fielding.

The positive attitude and behaviour on the part of Jackie had led to a change in the perceptions of his teammate and the whites of him. The blacks sometimes described him as impudent and brutal, which he actually was not. Jackie managed to gain the acceptance of his teammates because of his strong personality and his high motivation. $\mathrm{He}$ was emphatic.

\section{CONCLUSION}

The writer concluded that the motivation came from the drive to fulfil the lower needs to the high level of needs. Furthermore, the writer noticed that Jackie and Rickey had different level needs structures as their salient need at the given time. Such as : As for Jackie, the writer found that from 5 level of Maslow's Hierarchy of Human Needs, there were 2 salient needs; the belongingness and love needs, and the self-esteem need. As for Rickey, there was just 1 need he had to fulfil; the selfactualization need. The writer also noticed the process to fulfil the needs from one level needs to the higher one was not always in a hundred per cent to be fulfilled; otherwise the lower need could be partly fulfilled so they could go to the higher one as motivation.

Below was given such the result of the Hierarchy of Human Needs of the main characters which had been analysed:

1. Jackie Robinson: The Belongingness and Self EsteemNeeds and Love Needs: 7 sample of the effort, The Self-Esteem Needs: 2 sample of the effort

2. Branch Rickey: The selfactualization needs: 9 sample of the effort

From the result of the analysis, the writer found that great motivation also came from the men who had strong personality; Maturity and moral standard which became the keyword of the main characters to reach the goal. Jackie Robinson had good attitude and personal ethic to change the prejudice prevailing black people from his teammates and the white spectators into a positive perception such as acceptance, recognition, and respect.

Finally, the writer concluded that great motivation and strong personality 
led someone to attain the great achievement on their life. The real action, consistency and positive outlook were part of the personality that could support the motivation of the main characters.

The movie " 42 " was an interesting movie to be analysed in some aspects, but the writer only described the motivation and personality of the main characters due to the limitation of time. The analysis of the motivation and the personality of the main characters applied Maslow's Hierarchy of Human needs theory. Theoretically, The writer suggested that other theory could be applied in describing the motivation and personality for further research. In addition to analyse the motivation, the next research could analyse the racism and the perspective of the American society.

On the other hand, Jackie was a symbol of the integration in baseball which could break the colour barrier in this sport. This was the reason that Jersey number 42 had an important meaning of the history in the American major leagues baseball. As the matter of fact, The writer interpreted that Jackie was a hero for his own family and black people. He embodied his dream to be a great action to achieve the goal and became a role model for black youth.

Other essential thing the writer depicted from the movie was Jackie and Rickey described about the dream and the desire that they wanted to achieve should be accordance with the value and the belief of the society, and this should be started from them. To do the good thing for family and the society.

Thus, the movie " 42 " could motivate us as young generation, to be optimist to achieve the goals in the future and it also gave us a massage for the integration of human race and the peace of the world so that we could live together in peacefulness and harmony.

\section{REFERENCES}

American Psychological Association (2007). The Role Of The Situation in Leadership. Retrieved March 6, 2016, from Yale University.

Brian Helgeland (2013). 42 Movie Script. Retrieved March 6, 2016, from Im sDB http://www.imsdb.com/scripts/4 2.html.

Jacobs, CP (2016). Film Theory and Approaches to Criticism, or, what did that movie mean?. Retrieved February 21, 2016, from Christopher P. website:http://www.und.edu/inst ruct/cjacobs/FilmTheory\&Analy sis.htm.

John, S.(Ed.). (1998). Cultural Theory of Popular Culture, A Reader. (2nd ed.,48-56). Athens, The University of Georgia Press.

Luenberg,F.C. (2011, April 3). Expectancy Theory of Motivation: Motivating by Altering Expectations. Retrived from International Journal of Management, Business, and Administration. Vol. 15N1, Website:

http://www.nationalforum.com/J ournals/IJMBA/IJMBA.htm

Marciniak, M. (2016). The Appeal Of Literature-To-Film Adaptations. Retrieved February 21, 2016, from http://www.lingua.amu.edu.pl/Li ngua 17/lin-5.pdf. 
Robert, B.E. (2003). An Introduction To Theories Of Personality.(6th ed.,208-221). London, LEA: Lawrence Erlbaum Associates, Publisher.

Rogers, C.(2006). Personality Theories. In Dr.C.George Boeree (pp. 110). Pennsylvania: Psychology

\section{Department Shippensburg University).}

Strinati, D. (2004). An Introduction to Theories Of Popular Culture. (2nd ed.,4-310). London and New York, Routledge: Taylor and Francis Group 